\title{
Ruy Barbosa e o Direito das Gentes (1)
}

\section{Braz de Sousa Arruda}

Não me toca fazer o perfil do gigante do pensamento que a nossa estremecida patria acaba de perder, o Conselheiro Ruy Barbosa. Já lhe fundiram o busto em bronze os escultores, já lhe pintaram o retrato todos os inspirados pinceis, e já lhe descreveram o carater adamantino as penas dos verdadeiros patriotas e a palavra dos tribunos. Por todas as faces foi estudado o grande mestre, o guia da mentalidade brasileira nestes ultimos cincoenta anos. Em síntese, póde-se dizer que onde havia uma lágrima a enxugar, um sofrimento a aliviar, uma dor a consolar, ai se achava o santo varão que todos estremeciamos. Era o anjo tutelar dos que sofriam, e ao mesmo tempo o vingador dos oprimidos. Na tribuna e na imprensa, foi o defensor de todos os nobres ideais, e nunca sua pena intemerata deixou de estar ao serviço da liberdade do povo e dos sagrados direitos do homem, que ele fez assegurar na Constituição Brasileira, em que grande parte foi, inspirando-se quando nela trabalhava nas lições de Cristo cuja religião sempre confessou, mostrando quanto concorreu a doce doutrina do Evangelho para a felicidade e para o progresso do gênero humano. Em todos os trabalhos legislativos de vulto, não faltava a intervenção do indefesso batalhador, quer se tratasse da Constituição Federal, quer do Código Civil, quer doutra qualquer lei de importancia para os interesses bra-

(1) Lição inaugural do cunso de Direito das Gentes do 2.0 ano, am 1923. 
sileiros. Si a patria corria perigo, lá estava o guerreiro na estacada, ou em campo aberto, de viseira erguida, e pronto para atacar o adversario com a lealdade própria dos nobres combatentes que defendem, com fé, a patria e a justiça. A campanha que empreendeu em seu memoravel jornal "A Imprensa" foi, sabem-no todos, a causa real da queda do antigo regimen. Foi pelas colunas do terrivel órgão (que atacava qual ariete as muralhas do vetusto castelo monárquico) que o grande tribuno, defensor das idéias novas, conseguiu implantar no solo da patria o regimen que felizmente hoje nos rege. $\mathrm{E}^{\prime}$ a ele que se deve a liberdade de que gozamos, e, convencido o povo brasileiro desta verdade, de todos os lados erguem-se hoje vozes, fazendo-lhe o elogio funebre e lamentando a perda tremenda e irreparavel, e entoa-se um côro de hinos em louvor do grande homem que passou fazendo o bem aos seus compatriotas, e servindo a patria, que sempre foi o principal objeto de sua afeição.

Não é porém o trabalho da feitura de nossa Constituição e de nosso Cód go Civil, nem é a defesa dos fracos, nem é a luta pela imprensa pelos mais nobres ideais, nem é sua inspiração de orador, a rivalizar com Cicero e Demóstenes, nem a elegancia de sua linguagem transformando o nosso idioma, dando-lhe uma sonoridade nunca dantes conhecida, desbastando-lhe as asperezas e imprimindo-lhe um cunho correspondente á nossa cultura, mantendo o antigo mas melhorado e embelezado, não é de tão importantes serviços que me toca tratar agora, é só do internacionalista que me cumpre falar.

Nem só em Haya mostrou-se verdadeiro apóstolo da humanidade, advogado dos povos fracos contra a prepotencia e o poderio dos fortes, como o fôra sempre dos homens desvalidos nas relações internas, mas desde a proclamação da república, quando a nossa patria teve de dar ao mundo conta dos motivos por que mudára de fórma de govêrno. Foi então ele quem d.rigiu a ação do novo govêrno nesse terreno em 
que os homens do antigo regimen e do novo nada conheciam, habituados todos á ação pessoal do imperador, que fôra tudo nas relações internacionais, deixando muito pouca margem á iniciativa de nossos diplomatas no estrangeiro, e nenhuma aos políticos dentro dos limites de nosso território. Não fossem as dificuldades de comunicação pelo correio e pelo telegrafo, e a nossa diplomacia, durante o império, não teria existido, nenhum papel haveriam representado no cenário internacional os dois Paranhos, Lafayette, Cotegipe e outros vultos de que se honra a patria brasileira. Desde os primeiros anos pois da república, começou o Conselheiro Ruy a ser conhecido nos meios estrangeiros, e sua estada em Londres, durante o tempo em que dominou no Brasil o Marechal Floriano, foi cáusa de se tornar conhecido o nosso grande pais que teve a dita de ser a patria de tão peregrino engenho. Foram esses seus primeiros atos apenas os pródromos do que seria o ilustre patricio em tempos posteriores, quando a humanidade ansiosa procurasse em Haya, em 1901, uma fórmula para evitar a guerra, tão detestada em todos os tempos, e incompativel hoje com a nossa cultura, e quando a Alemanha em 1914, rompendo todas as promessas de cordura que os povos se faziam, desfazendo a história para voltar aos tempos da barbaria, levaria a guerra ás mais pacíficas nações da terra, e, emboscada em portos de nações neutras, atacaria, qual salteador deshumano, os nossos navios, que conduziam o produto de nosso trabalho e as nossas riquezas. Ante o desrespeito á nossa dignidade, ante o torpedeamento sistemático de nossos navios mercantes, ante tantas e tão duras provocações, suscetibilizado pela atitude do povo que voltava á mais rude selvageria, e que desrespeitava todas as leis e todos os tratados, que o progresso dos sentimentos cristãos e o desenvolvimeno da doutrina de Cristo implantaram nos povos cultos, levantou-se a voz do homem que era um vulcão quando indignado, e sua palavra inspirada foi á Argentina pregar a cruzada contra os bárbaros que dominavam o mar, novos piratas, pois dos antigos já a cul- 
tura humana limpára o oceano, que se tornara o caminho franco para as frotas mercantes, pacificas, auxiliadoras do trabalho honesto, e que favorecem a aproximação dos povos.

Mas qual sua missão em Haya, onde tão alto elevou o nome brasileiro? Foi lá que culminou o seu talento no céu em que brilham as estrelas que presidem aos destinos dos povos, foi tambem lá que o Brasil começou a ser considerado como um país em que se cuida das relações internacionais, e em que ha homens que podem, por seu vasto descortino e por sua cultura, influir na sorte do mundo culto. Não o dizemos nós, mas dizem os estrangeiros que o papel do Conselheiro Ruy nesse Congresso em que o mundo se fez representar pelo seu escól, foi o de um apóstolo da paz, e que sua superioridade a todos os membros da grande assembléia não pode ser negada. Não queremos nós seus concidadãos encarecer-lhe o mérito, foram os orgulhosos europeus, que supunham um território bárbaro este que se estende do Amazonas ao Prata, que confessaram a elevação de idéias do nosso patrício e sua rara cultura servida por um lúcido espirito ao qual nenhum se igualava.

Corria o ano de 1907. Quarenta e quatro nações se faziam em Haya representar pelo que de mais notavel tinham dentre seus filhos. A Alemanha, segundo refere William Stead, forte pelo seu colossal exército, e representada pelo orgulhoso barão de Marschal, recusava abertamente a ouvir os oradores sul-americanos. Nunca, diz o mesmo Stead, respondeu a um único argumento que fosse dos representantes das repúblicas latinas do Novo Mundo. Uma exceção abria, e essa era concedida ao Conselheiro Ruy: é que o soberbo representante da Alemanha e do orgulho germânico sentia que a palavra do orador brasileiro era uma força superior ao exército com que, em Sedan, o império (cujos dias estavam contados) vencêra a França, e impusera, á república nossa amiga e hoje nossa aliada pelo Tratado de Versalhes, tudo quanto era destinado a humilhar a nação 
que marcha na vanguarda do progresso, e que, ainda vencida, não dobrou a cerviz e soube ser altiva, sem apelar para a misericórdia do vencedor nem para o auxílio dos demais povos que não tinham que ver com a sua luta com o império vizinho. Com efeito, com razão temia Marschal a Ruy, e mostrava-se previdente, pois foi a conferência de Buenos Aires que acordou a conciencia humana, e que moveu os povos do continente sul americano a abraçar a cáusa da França contra o império que torpedeava os nossos navios, assassinava os nossos irmãos, e que não nos dava explicações, como não dava resposta aos representantes das nações sul americanas no Congresso de Haya, exceptuado o grande Conselheiro Ruy, cujo mérito seria tão ridículo encobrir, quanto pretender escurecer a luz do sol que brilha ao meio dia.

Nomeado, por indicação da Rússia, para presidente da primeira comissão, quando o fôra só para o da segunda o representante da Alemanha, não podia o nome de nosso patrício deixar de chamar a atenção de todos os membros do Congresso. A princípio, quiseram tratá-lo como a um rastacuere, com que se divertem os chistosos parisienses, julgando que representam esses ridículos americanos a média de nossa intelectualidade, mas, depois, quando lhe sentiram o pulso hercúleo de lutador invencivel, começaram a compreender que duas forças havia no Congresso: a da Alemanha com o seu exército, e a do Brasil com esse novo David, capaz de, com sua fé, e o auxilio de Deus que lhe outorgara o gênio, fazer tombar o gigante de além do Reno, como derrubára já o império brasileiro.

As mais delicadas questões foram com suma pericia tratadas pelo grande internacionalista, e basta citar a da proposta Drago, contra a qual ele deveria se bater, mas sem suscetibilizar as nações irmãs. Disse ele, dando conta da dificuldade de sua posição e de quanto melindre deveria ter para não magoar a suscetibilidade das nações do Novo Continente: "Quasi todas elas viam na doutrina de Drago um escudo á dignidade e integridade de nosso con- 
tinente, contra a ameaça de violentas demonstrações européias, como a de que tinham sido objeto Venezuela, senão ainda mais graves." Aumentava sua dificuldade o fato de ter-se batido pela abolição do direito de captura que algumas naçōes sul americanas advogavam contra os Estados Unidos. Zeballos, levado por um sentimento injusto, mas respeitabilissimo, pois era nascido de seu patriotismo, teve na conferencia alguns atritos com o Conselheiro Ruy, mas, com o tempo, refletindo calmamente, seu espirito clarividente, já desonubilado, reconheceu que era com o nosso patrício que estava a razão, e foi naturalmente por esse motivo que, em 1914, of ereceu ao grande brasileiro uma coleção de suas obras com dedicatorias sumamente honrosas para o saudoso representante da nossa patria em Haya.

Constituira-se na assembléia o célebre "Comité des Sept", que foi cognominado a "Comissão dos Sete Sábios". Compunha-se dos embaixadores dos Estados Unidos, da França, da Alemạnha, da Rússia, da Austria Hungria, da Itália e do Brasil. A estes veio unir-se, pouco depois, o da Inglaterra, continuando o Comité com seu nome primitivo, quiçá por ser o numero sete tido por fatídico. Como se vê, só o Conselheiro Ruy nele representava uma nação militarmente fraca, devendo-se haver a comissão como sendo a representante do poderio militar, da força material, do que, em suma, se denomina a superioridade de uma grande potencia. Era ele quem falava, dentro da comissão, pelas nações fracas, e, por isto mesmo, veio a ser o representante das nações sul americanas. Mas não se lembravam os da assembléia de que, com a palavra, derribara o Conselheiro Ruy o império brasileiro, e, si houvesse aos representantes dos exércitos, assaltado o espírito essa recordação é provavel que compreendessem que bem poderia nove anos depois, em Buenos Aires, a palavra inspirada do grande orador eletrizar as nações americanas, acordar o brio daquelas que eram ultrajadas pelo império alemão a torpedear seus navios, e vir a derrocar o velho imipério dos Hohenzolerns. Sim: o resultado da conflagração 
européia exprime-se em póucas palavras: foram o Conselheiro Ruy, no Sul, e Woodrow Wilson, no Norte, que moveram a América a ir dar o apôio necessario aos aliadns, afim de que repelissem dos muros de Paris a Alemanha quasi vitoriosa. Não fosse o auxílio desses dois benfeitores da humanidade, e outra seria a sorte do mundo, entregue á ferocidade germânica, quiçá engolfado em trevas, tornado ao período das guerras sem treguas.

Infelizmente nesse Congresso, destinado a buscar a paz entre as nações, em que discutiam seus membros a abolição da captura, a arbitragem obrigatória, a inviolabilidade da propriedade privada no mar, a doutrina Drago, a abolição do contrabando de guerra, ou, ao menos, a sua definição ou determinação dos artigos como tais considerados, o bloqueio, a permanencia dos navios beligerantes nos portos neutros, a transformação de navios mercantes em navios de guerra, o recurso das decisões dos tribunais de presa para tribunais de $2 \mathrm{a}^{\mathrm{a}}$ instancia, como início de julgamento obrigatório, por tribunais, de todas as questões internacionais, os deveres dos neutros, a colocação das minas pelos neutros, infelizmente, repito, por um fenômeno de sobrevivencia de idéias dos tempos passados, permanecia como critério da supremacia dos povos a força militar. Foi contra essa tendencia, verdadeiro anacronismo, que teve de se bater o Conselheiro Ruy.

Recorda-me, de meus estudos de latim, o que nos Comentarios da Guerra das Galias dizia Cesar para defender seus atos, e dessa lembrança tiro hoje quanta grandeza de espirito, quanta vastidão de vista, quanta perspicácia, quanta clarividencia tinha o grande conquistador das Galias, e, ao mesmo tempo, organizador de Roma. Não obstante a força de que dispunha, sem embargo de sua habilidade de grande general, seguro de que, no campo de batalha, seu gênio o fazia superar todos os adversários, nunca começou uma campanha sem primeiro provar a seus inimigos que tinha por si a justiça e se limitava a defender os direitos 
de um povo virtuoso, justo e temente ás leis divinas e humanas. Por que o fazia? que o grande capitão compreendia que, si seu ataque não tivesse apôio na conciência dos povos de então, estaria ele sujeito a uma coligação dos fracos, e logo se empanaria o brilho da estrela que o guiava. A mais rápida leitura da obra do invencivel capitão romano e invejavel estilista, logo faz sentir, através das frases de elegancia lapidar de suas obras, que eram as coligações o fantasma que o assombrava, noite e dia, em sua tenda de campo. E foi a coligação dos povos latinos e saxônios no Novo Mundo que derrocou o velho e poderoso império, diante do qual tremeu o mundo em 1870, e quarenta e quatro anos mais tarde, quando impudente e imprudentemente proclamou que os tratados eram farrapos que não mereciam respeito, violou o território da Bélgica, e do Luxemburgo, e caiu de improviso sobre a França, que julgava o primeiro ponto em que firmaria o pé para dominar o universo.

Não me é possivel pintar com as cores vivas com que pintou o verbo inflamado do artista da palavra o que foi essa guerra tremenda, cuja só descrição na conferencia de Buenos Aires faz arrepiar os cabelos a todos e perguntar si era possivel, em pleno seculo XX, tanta barbaridade. Deixo este ponto, e passo ao encerramento da conferencia de Haya.

Vencêra afinal a opinião de que os povos se classificam pelo poderio militar. A dor que alanceou o peito do amigo da paz é inenarravel. Vai dizer as ultimas palavras, e profetizar as consequencias do erro cometido pelos companheiros. Sua voz na novissima verba tem o tom dolente dos que choram uma desgraça. Ha um quê de bíblico em seu discurso, e faz lembrar os profetas, ao entrarem nos palácios dos reis para dizerem duras verdades, sem ambages, nem rebuço. Afirmam que houve em tal oração uma ameaça velada por parte do embaixador brasileiro, mas eu não vejo onde esse disfarce. $O$ grande brasileiro assoma á tribuna, e, depois de recordar o que se pas- 
sara, refere isto que a todos nos causa diariamente admiração, sem embargo de ser coisa sempre vista e já de nós conhecidissima: o desenvolvimento de nossa patria de modo prodigioso, como só sucede nos paises novos nos tempos modernos. Da noite para o dia, formam-se cidades, a população dobra, triplica, a riqueza é aumentada em uma progressão nunca vista, nem sonhada, onde havia um deserto, surge uma cidade belissima, quem hontem era pauperrimo, é hoje riquissimo, e Job da vespera será o Creso do dia seguinte, e, si assim é, si temos riqueza, rápido desenvolvimento, e si não nos falta patriotismo, por que não será o Brasil amanhã uma potencia igual, sinão superior, ao Japão? Basta ao colosso sul americano o querer, e a bravura de Caxias, Osorio, Saldanha da Gama, Inhauma, Amazonas e tantos e tantos outros terá os meios de fazer o Cruzeiro do Sul dominar o mundo, e ser temido nas conferencias, como foi a de Haya: uma assembléa em que se louvava a paz e se rendia preito ao poder militar das nações belicosas. Mas não foi esta a única dor que sofreu o grande patrício, pois seu coração ainda foi alanceado pela afirmativa de que faltava ao Brasil a probidade necessaria para ser juiz nas pendencias internacionis. Cita o nosso patrício, rememorando glorias de nosso passado, os nomes do Visconde de Itajubá, do Barão de Arinos, de Lopes Neto, Lafayette Pereira e Agujar Andrade, nomes imorredouros, juizes que colheram, nos tribunais internacionais, louros imarceciveis, para si e para a nossa querida patria.

Eis, senhores, quem foi o Conselheiro Ruy Barbosa na qualidade de internacionalista, eis os serviços que prestou á patria e á humanidade, eis o que fez em Haya e em Buenos Aires, influindo de modo decisivo na vida dos povos cultos e na sorte da humanidade. Os historiadores que se ocuparem de nossos tempos, ao narrarem os acontecimentos do seculo XX, não poderão deixar de dar como uma das causas dos acontecimentos de nossos dias a influencia de nosso compatriota. 